\title{
Manajemen Perencanaan Dalam Keperawatan
}

\author{
Nikita Gina Chesena Sembiring \\ nikitagina.ng@gmail.com
}

\section{LATAR BELAKANG}

Pelayanan keperawatan sebagai salah satu pelayanan utama di rumah sakit merupakan bagian yang tidak terpisahkan. Mutu pelayanan keperawatan sebagai indikator kualitas pelayanan kesehatan menjadi salah satu faktor penentu citra institusi pelayanan kesehatan di mata masyarakat. Hal ini terjadi karena keperawatan merupakan kelompok profesi dengan jumlah terbanyak, paling depan dan terdekat dengan penderitaan, kesakitan, serta kesengsaraan yang dialami pasien dan keluarganya.

Keperawatan merupakan suatu bentuk pelayanan profesional bersifat humanistik, menggunakan pendekatan holistik, dilakukan berdasarkan ilmu dan kiat keperawatan, berorientasi kepada kebutuhan objektif klien. Praktik keperawatan mengacu pada standar profesional keperawatan dan menggunakan etika keperawatan sebagai tuntutan utama titik perawat dituntut untuk selalu melaksanakan Asuhan Keperawatan yang benar atau rasional (Nursalam, 2007).

Tujuan profesi keperawatan adalah memberikan pelayanan kepada klien dan juga mempertahankan kehidupan profesi itu sendiri (Keyzer,1992 dikutip dalam Draper 1996). Untuk mencapai tujuan tersebut perawat perlu memiliki keterampilan intelektual teknikal, interpersonal dan etik. Semua keterampilan ini harus tampak dalam pemberian asuhan keperawatan kepada klien. Praktik keperawatan profesional adalah praktek yang didasari dengan keterampilan intelektual teknikal, interpersonal dengan menerapkan suatu metode asuhan yang dapat dipertanggungjawabkan secara ilmiah.

Manajemen Asuhan Keperawatan yang baik sangat dibutuhkan dalam memberikan asuhan keperawatan kepada klien secara sistematis dan terorganisir. Manajemen asuhan keperawatan merupakan pengaturan sumber daya dalam menjalankan kegiatan dengan menggunakan metode proses keperawatan untuk memenuhi kebutuhan klien atau menyelesaikan masalah (Keliat, 2000).

Proses asuhan keperawatan adalah suatu rangkaian asuhan yang terdiri dari pengkajian, menyusun diagnosa keperawatan, perencanaan tindakan, implementasi dan 
evaluasi. Proses keperawatan adalah suatu pendekatan penyelesaian masalah yang sistematis dalam pemberian asuhan keperawatan. Kebutuhan dan masalah klien merupakan titik sentral dalam proses penyelesaian masalah.

Tujuan proses keperawatan secara umum adalah membuat suatu kerangka konsep berdasarkan Kebutuhan individu keluarga dan masyarakat Seperti yang disampaikan oleh Yura dan Walsh (1983) bahwa proses keperawatan adalah suatu tahapan desain tindakan yang ditujukan untuk memenuhi tujuan keperawatan meliputi: mempertahankan kesehatan optimal, kembali ke keadaan normal, dan manfaat fasilitas kualitas hidup.

Perencanaan merupakan fungsi manajemen pertama yang sangat menentukan dan mempengaruhi keberhasilan dari fungsi-fungsi manajemen lainnya. Perencanaan harus dikerjakan lebih dahulu sebelum mengerjakan fungsi manajemen yang lainnya. Perencanaan yang baik akan mengarahkan pada pencapaian tujuan, sehingga hasil sistem kontrol diharapkan berjalan dengan baik yang pada akhirnya akan memudahkan pencapaian tujuan organisasi.

Perencanaan adalah satu langkah penting yang harus diperhatikan Seorang perawat sebelum memberikan tindakan keperawatan. Perencanaan meliputi pengembangan strategi desain untuk mencegah mengurangi atau mengoreksi masalah-masalah yang diidentifikasi pada diagnosa keperawatan (Lyer et al,. 1996 dalam Nursalam,2008). Rencana tindakan dilaksanakan berdasarkan komponen penyebab dari diagnosa keperawatan. Oleh karena itu, rencana mendefinisikan suatu aktivitas yang diperlukan untuk membatasi faktor-faktor pendukung terhadap suatu permasalahan.

Intervensi atau Rencana tindakan keperawatan merupakan serangkaian tindakan yang dapat mencapai setiap tujuan khusus. Perencanaan keperawatan meliputi perumusan tujuan, tindakan dan penilaian rangkaian asuhan keperawatan pada klien berdasarkan analisis pengkajian agar masalah kesehatan dan keperawatan klien dapat diatasi.

\section{METODE}

Kajian ini dilakukan dengan metode menganalisis dari berbagai sumber bacaan. Baik dari berbagai jurnal online, skripsi, tesis, buku ataupun e-book, yang memiliki hubungan dengan Perencanaan dan Pengorganisasian Dalam Keperawatan. 
Penulisan kajian ini melakukan metode perbandingan antar satu artikel dengan artikel lainnya. Kemudian perbandingannya ditulis secara beraturan dalam hasil dari kajian. Dengan isi yang akan dibandingkan tetap berhubungan dengan Perencanaan dan Pengorganisasian Dalam Keperawatan.

\section{HASIL}

Hasil penelitian ini mendukung hasil penelitian sebelumnya dari Rustam Efendi, Alwy Arifin, dan Darmawansyah (2014), dengan judul "Hubungan Mutu Pelayanan Kesehatan Dengan Kepuasan Pasien Rawat Jalan Di Puskesmas Aeng Towa Kabupaten Takalar ". Berdasarkan hasil analisis deskriptif masing-masing indikator pada variabel intervensi, maka dapat disimpulkan bahwa indikator keempat (x3.4) yaitu harga diri, mendapatkan respon tertinggi yaitu dengan rata-rata jawaban responden yakni sebesar 4.23 yang masuk pada kategori sangat tinggi. Sedangkan pada indikator ketiga (X3.3) yaitu mencintai dan memiliki, mendapat respon terendah yaitu dengan rata-rata jawaban responden yakni sebesar 4.00 yang masuk pada kategori tinggi. Dalam hal ini terlihat bahwa intervensi dalah hal ini pernyataan bahwa perawat menjelaskan tentang rencana tindakan penyuluhan terkait masalah kesehatan yang dialami, agar pasien lebih memahami dan tetap merasa percaya diri direspon sangatlah baik. Sehingga hal ini perlu dipertahankan. Adapun terkait dengan pernyataan bahwa perawat melibatkan keluarga pasien dalam perencanaan tindakan keperawatan sehingga hubungan tetap terjalin baik yang direspon rendah menjadi bahan evaluasi bagi Puskesmas Takalala Kabupaten Soppeng agar intervensi keperawatan dapat semakin baik diterapkan terhadap pasien dan lebih ditingkatkan.

Dalam Jurnal Kinerja dan Lingkungan Kerja Perawat Pelaksana Dalam Melaksanakan Asuhan Keperawatan (Miming Oxyandi, 2018) Penelitian ini menunjukkan perencanaan keperawatan telah mencapai standar yang ditetapkan Depkes RI yaitu 75,7\%. Rencana asuhan keperawatan yang di rumuskan dengan tepat memfasilitasi kontinuitas asuhan perawatan dari satu perawat ke perawat lainnya. Sebagai hasil, semua perawat mempunyai kesempatan untuk memberikan asuhan yang berkualitas tinggi dan konsisten. Sedangkan implementasi yang merupakan tindakan atau aplikasi dari rencana asuhan keperawatan untuk mencapai tujuan yang diharapkan diperoleh nilai pencapaian sebesar $72,9 \%$ belum memenuhi standar Depkes. 
Sedangkan penelitian Siahaan, (2011) menunjukkan perencanaan dan implementasi juga belum mencapai standar yang ditetapkan Depkes RI. Implementasi merupakan tindakan atau aplikasi dari rencana asuhan keperawatan untuk mencapai tujuan yang diharapkan.

Artikel hasil penelitian dari Bhutan, Community directed educational intervention for malaria elimination in Bhutan: quasiexperimental study in malaria endemic areas of Sarpang district (Tashi et al, 2013). Temuan Ada peningkatan yang signifikan dalam pengetahuan dan sikap pada kelompok intervensi bila dibandingkan dengan kontrol selama survei pasca intervensi ( $\mathrm{p}<0,001)$. Rata-rata nilai tindakan lebih tinggi pada kelompok kontrol selama pra dan pasca intervensi, namun rata-rata $( \pm S D)$ nilai tindakan pencegahan di kelompok intervensi meningkat dari $6.84 \pm 1.26$ pada pra intervensi dan $8.35 \pm 1.14$ pada pasca intervensi $(\mathrm{p}<0,001)$. Kesimpulan Intervensi Community directed educational berkontribusi menurunkan prevalensi malaria pada anak-anak melalui peningkatan pengetahuan dan praktik pencegahan.

Artikel hasil penelitian dari Nigeria, Impact of health education intervention on malaria prevention practice among nursing mothers in rural communites in Nigeria (Amoran, 2013). Temuan Pengetahuan tentang penyemprotan dalam ruangan meningkat dari $14,7 \%$ menjadi 58,2\% ( $\mathrm{p}<0,001$ ) dan penggunaan ventilasi berjaring nyamuk meningkat dari 48,3\% menjadi 74,8\% ( $p<0,001$ ). Proporsi orang yang menggunakan ITN meningkat dari $60,8 \%$ menjadi 97,4\% ( $\mathrm{p}<0,001)$ sementara praktik menjaga lingkungan yang bersih juga meningkat dari 50,4\% menjadi 64,5\% ( $\mathrm{p}<0,001$ ). Kesimpulan Health education intervention efektif dalam meningkatkan pengetahuan, sikap, dan praktik pencegahan malaria di antara ibu-ibu balita di daerah pedesaan.

Artikel hasil penelitian dari Brazil, Effect of participatory educational program on primary school teachers knowledge of malaria in Barcelos, Northem Brazil (Cecilia et al, 2011). Temuan : Terjadi peningkatan pengetahuan tentang malaria pada guru SD: mekanisme penularan dari $29,8 \%$ menjadi $76,5 \%(\mathrm{p}=0,01)$ dan cara pencegahan meningkat dari $61,4 \%$ jadi 94,6 \% (p=0,000005). Kesimpulan Educational Program dapat meningkatkan pengetahuan tentang malaria, misalnya mekanisme penularan dan cara pencegahanpenularan malaria.

\section{PEMBAHASAN}


Pelayanan keperawatan di rumah sakit dan Puskesmas adalah salah satu jenis pelayanan profesional yang dilaksanakan oleh rumah sakit dan Puskesmas untuk melayani kebutuhan Masyarakat khususnya dalam bidang keperawatan yang diorganisir melalui pelayanan keperawatan.

Perawat membuat rencana tindakan keperawatan untuk mengatasi masalah dan meningkatkan kesehatan klien (Nursalam, 2007). Kriteria proses meliputi:

- Perencanaan terdiri atas penerapan prioritas masalah, tujuan dan rencana tindakan keperawatan

- Bekerjasama dengan klien dalam menyusun rencana tindakan keperawatan

- Perencanaan bersifat individual sesuai dengan kondisi atau kebutuhan klien

- Mendokumentasikan rencana keperawatan

Komponen perencanaan keperawatan terdiri atas:

1) Prioritas Masalah

Kriteria antara lain sebagai berikut :

- Masalah yang mengancam kehidupan merupakan prioritas utama

- Masalah yang mengancam kesehatan seseorang merupakan prioritas kedua

- Masalah yang mempengaruhi perilaku merupakan prioritas ketiga

2) Tujuan Asuhan Keperawatan, memenuhi syarat SMART (Specific, Measurble Achievable Reasonable Time)

Kriteria NOC (Nursing Outcome Criteria) disesuaikan standar pencapaian sebagai berikut :

- Tujuan dirumuskan secara singkat

- Disusun berdasarkan diagnosis keperawatan

- Spesifikasi berdasarkan diagnosis keperawatan

- Dapat dipertanggungjawabkan secara ilmiah

- Ada target waktu pencapaian

3) Rencana tindakan didasarkan pada NIC (Nursing Intervention Classification) yang telah ditetapkan oleh instansi pelayanan setempat. Jenis rencana tindakan keperawatan mengandung tiga 
komponen, meliputi DET tindakan keperawatan, yaitu sebagai berikut:

- Diagnosis/observasi

- Edukasi (HE)

- Tindakan independen, dependen dan interdependen.

Kriteria meliputi hal sebagai berikut:

- Berdasarkan tujuan asuhan keperawatan

- Merupakan alternatif tindakan secara tepat

- Melibatkan pasien atau keluarga

- Mempertimbangkan latar belakang sosial budaya pasien atau keluarga

- Mempertimbangkan kebijaksanaan peraturan yang berlaku

- Menjamin rasa aman dan nyaman bagi pasien

- disusun dengan mempertimbangkan lingkungan, sumber daya, dan fasilitas yang ada

- Harus berupa kalimat instruksi, ringkasan, tegas dan penulisan menggunakan bahasa yang mudah dimengerti

- Menggunakan formulir yang baku

Ada beberapa komponen dari rencana tindakan keperawatan yaitu:

- Waktu, di mana semua rencana keperawatan harus diberi waktu untuk mengidentifikasi tanggal dilaksanakan.

- Menggunakan kata kerja, semua rencana tindakan harus secara jelas menjabarkan setiap kegiatan.

- Fokus pada pertanyaan, spesifik hal ini sangat penting untuk membuat rencana tindakan menjadi bermakna.

- Modifikasi pengobatan, tujuannya adalah untuk membatasi penulisan tindakan yang berulang-ulang.

- Tanda tangan, hal ini merupakan aspek hukum yang bisa dipertanggungjawabkan.

Metode tim akan berjalan dengan baik jika didukung oleh kepala ruangan yang berperan sebagai manager di ruangan. Dalam perencanaan kepala ruangan bertanggung jawab dalam:

- Menunjuk ketua tim yang akan bertugas di ruangan. 
- Mengidentifikasi tingkat ketergantungan pasien gawat, transisi dan persiapan pulang bersama ketua tim.

- Mengidentifikasi jumlah perawat yang dibutuhkan berdasarkan aktivitas dan kebutuhan pasien bersama ketua tim, mengatur penugasan penjadwalan.

- Merencanakan strategi pelaksanaan asuhan keperawatan.

- Membantu staf dalam menetapkan sasaran asuhan keperawatan.

Perencanaan keperawatan adalah suatu proses di dalam pemecahan masalah yang merupakan keputusan awal tentang sesuatu apa yang akan dilakukan, bagaimana dilakukan, kapan dilakukan, siapa yang melakukan dari semua tindakan keperawatan. Tujuan rencana tindakan dibagi menjadi dua menurut Dermawan (2012) yaitu :

a) Tujuan administratif

1. Untuk mengidentifikasi fokus keperawatan kepada pasien atau kelompok

2. Untuk membedakan tanggung jawab perawat dengan profesi kesehatan lainnya

3. Untuk menyediakan suatu kriteria guna pengulangan dan evaluasi keperawatan

4. Untuk menyediakan kriteria klasifikasi pasien

b) Tujuan klinik

1. Menyediakan suatu pedoman dalam penulisan

2. Mengkomunikasikan dengan staf perawat; apa yang diajarkan, di observasi dan dilaksanakan.

3. Rencana tindakan yang spesifik secara langsung bagi individu, keluarga, dan tenaga kesehatan lainnya untuk melakukan tindakan.

\section{A. Hakekat Perencanaan}

Aspek utama dalam manajemen adalah pengaturan dan penggerakan karyawan melalui proses kepemimpinan (Gitosudarmo, 2001). Untuk dapat melakukan pengaturan yang 
baik maka perlu perencanaan, pembagian tugas dan koordinasi tugas-tugas, Oleh karena itu perencanaan merupakan aspek utama dan pertama kali harus dilakukan oleh seorang manajer atau pimpinan organisasi. Hasil dari perencanaan adalah sebuah rencana atau Rencana kerja yang harus berisi alternatif terbaik untuk mencapai tujuan.

Perencanaan adalah upaya manusia secara sadar memilih alternatif masa depan yang dikehendaki dan kemudian mengarahkan sumber daya untuk mewujudkan tujuan (Gitosudarmo, 2001). Perencanaan adalah proses pengambilan keputusan manajerial yang mencakup penelitian lingkungan, penggambaran sistem organisasi serta keseluruhan memperjelas; misi dan filosofi organisasi, memperkirakan sumber daya organisasi, mengidentifikasi dan memilih langkah-langkah tindakan, memperkirakan efektivitas tindakan dan menyiapkan karyawan untuk melaksanakannya (Gilles, 1994).

B. Tujuan Perencanaan

Tujuan perencanaan dalam manajemen:

- Meningkatkan peluang untuk sukses

- Menstimulasi berpikir analisis

- Mencegah terjadinya krisis manajemen

- Memfasilitasi berpikir kritis dan membuat keputusan secara fleksibel

- Meningkatkan keterlibatan staf dan komunikasi

- Menjamin biaya yang efektif

C. Perencanaan Dalam Manajemen Keperawatan

Perencanaan manajemen keperawatan diawali dengan perumusan tujuan institusi/ organisasi yang dijelaskan dalam visi misi, filosofi dan tujuan sebagai arah kebijakan organisasi. Sebagai perawat harus memahami tujuan organisasi supaya dapat bersinergi untuk mencapai cita-cita atau harapan organisasi.

\section{a. Perumusan Visi}

Sisi merupakan dasar untuk membuat suatu perencanaan sehingga disusun secara singkat, jelas, dan mendasar serta ada batasan waktu untuk pencapaian. Visi merupakan pernyataan berisi tentang Mengapa organisasi dibentuk. Contoh rumusan visi: "Menjadi ruang perawatan bedah yang melakukan perawatan profesional dan unggul dalam manajemen perawatan luka modern di tahun 2018". 


\section{b. Perumusan Misi}

Misi adalah uraian yang berisi pernyataan operasional guna mencapai visi yang telah ditetapkan, contoh misi ruang perawatan bedah yang mengacu pada visi tersebut di atas adalah:

i. Memberikan asuhan keperawatan pada pasien bedah secara holistik bio-psiko-sosio-kultural dan spiritual

ii. Melakukan tindakan perawatan luka dengan menggunakan manajemen perawatan luka modern

iii. Menyediakan sarana prasarana untuk menunjang manajemen perawatan luka modern

iv. Melakukan penelitian tindakan bedah berdasarkan perkembangan dan trend perawatan bedah

\section{c. Perumusan Filosofi}

Filosofi adalah nilai nilai dan keyakinan yang menyangkut keyakinan dan praktik keperawatan dalam suatu organisasi (Swanburg, 1999). Contoh:

- Pasien adalah manusia yang merupakan makhluk holistik (bio-psiko-sosialspiritual)

- Pasien adalah individu yang unik dan bermartabat d. Perumusan Tujuan

Tujuan merupakan sesuatu yang ingin dicapai sebagai arah kebijakan bagi organisasi untuk menentukan apa yang harus dilakukan dan bagaimana cara pencapaiannya. Tujuan mutlak harus ada dalam organisasi pelayanan keperawatan. Untuk merumuskan tujuan yang baik harus memenuhinya antara lain(Gillies, 1994):

1. Tujuan harus dapat menjelaskan arah

2. Tujuan harus memungkinkan untuk dicapai

3. Terukur artinya tujuan berarti ketentuan kuantitatif

4. Terdapat batasan waktu untuk pencapaian target

5. Pencapaian akhir setiap tujuan dapat diterima semua anggota organisasi

6. Kriteria dibuat untuk melihat seberapa besar tujuan tercapai

7. Setiap tujuan mendukung sasaran organisasi 
Contoh : meningkatkan kualifikasi tenaga perawatan yang handal dan competent dalam keperawatan bedah melalui pendidikan dan pelatihan.

\section{Jenis Perencanaan Dalam Manajemen Keperawatan}

Perencanaan dalam manajemen keperawatan berdasarkan jangka waktu dibagi menjadi tiga jenis yaitu, perencanaan jangka pendek jangka menengah dan jangka panjang.

Perencanaan jangka pendek atau yang disebut sebagai perencanaan operasional adalah perencanaan yang dibuat untuk kegiatan dengan kurun waktu satu jam sampai dengan satu tahun. Perencanaan jangka menengah adalah perencanaan yang dibuat untuk kegiatan dengan kurun waktu antara satu tahun sampai dengan lima tahun (Marquis \& Huston, 1998), sedangkan perencanaan jangka panjang atau sering disebut perencanaan strategis adalah bagian dari manajemen strategi, yang memiliki arti suatu perencanaan sebagai tindakan adaptif atau penyesuaian terhadap tuntutan atau masalah atau perubahan yang ada di lingkungan organisasi sehingga organisasi dapat melakukan tindakan adaptif dalam tuntutan perubahan. Perencanaan jangka panjang yang didalamnya terdapat kesepakatan misi dan tujuan perusahaan, sehingga membagi perencanaan strategis meliputi tahap inisiasi proses, aturan tujuan, arti dan akhir dari hubungan, penjelasan dari perencanaan strategis dan tingkat kepuasan yang terintegrasi.

Dalam perencanaan di ruang perawatan biasa yang digunakan adalah perencanaan jangka pendek yaitu rencana harian, bulanan dan rencana tahunan. Rencana harian adalah rencana yang berisi kegiatan masing-masing perawat yang dibuat setiap hari sesuai perannya. Rencana dibuat oleh kepala ruang, ketua tim/perawat primer dan perawat pelaksana. Rencana bulanan adalah rencana yang berisi kegiatan dalam satu bulan titik rencana. Rencana ini harus disinkronkan dengan rencana harian. Rencana ini biasanya dibuat oleh kepala ruang dan ketua tim/perawat primer. Rencana tahunan adalah rencana yang dibuat setiap tahun sekali yang dibuat berdasarkan hasil evaluasi kegiatan tahun sebelumnya, rencana ini biasa dibuat oleh kepala ruang.

Menurut waktu pembuatan perencanaan dapat diklasifikasikan dalam: 1) perencanaan reaktif suatu perencanaan yang disusun ketika adanya masalah aktual yang dihadapi saat ini. 2) perencanaan proaktif yaitu perencanaan yang disusun sebelum masalah timbul, antisipasi terhadap perubahan kebutuhan dan meningkatkan kemampuan organisasi. Sedangkan menurut proses penyusunan perencanaan dikasih diklasifikasikan menjadi: pendekatan 
perkembangan yang menguntungkan (Profitabel Growth Approach) dan pendekatan analisis SWOT (Strenght, Wakness, Opportunity, dan Treat).

1. Pendekatan Perkembangan yang Menguntungkan (Profitabel Growth Approach)

Pendekatan perkembangan yang menguntungkan adalah perencanaan yang dilakukan dengan menganalisa sasaran produksi yang dimiliki dan dihubungkan dengan kebutuhan yang muncul dari lingkungan. Mengusahakan terjadinya keseimbangan antara sarana yang dimiliki dengan kebutuhan lingkungan.

\section{Pendekatan SWOT}

Rencana disusun dengan proses perencanaan, dimulai dengan menganalisa faktor internal yang berhubungan dengan kekuatan (strenght) dan kelemahan (wakness), selanjutnya melakukan analisa faktor eksternal yang berhubungan dengan peluang(opportunity) dan tekanan/ancaman (treat). Setelah diketahui kekuatan kelemahan peluang dan ancaman selanjutnya disusun rencana strategis untuk mencapai tujuan organisasi. Rencana strategis harus diterjemahkan kedalam rencana operasional yang mencantumkan target yang harus dicapai.

Perencanaan keperawatan yang juga penting adalah perencanaan SDM khususnya SDM keperawatan. Adapun tujuan perencanaan SDM keperawatan adalah:

1. Menentukan kualitas dan kuantitas tenaga keperawatan contoh perencanaan kebutuhan perawat berdasarkan tingkat pendidikan (D3, Ners, Ners spesialis)

2. Peminatan SDM keperawatan sesuai minat, spesialisasi, dan kualifikasi pendidikan yang tepat.

3. Menjamin tersedianya tenaga keperawatan masa sekarang maupun masa mendatang

4. Menghindari tumpang tindih pelaksanaan tugas

5. Mempermudah koordinasi integrasi dan sinkronisasi 


\section{PENUTUP}

\section{KESIMPULAN}

Keperawatan merupakan suatu bentuk pelayanan profesional bersifat humanistik, menggunakan pendekatan holistik, dilakukan berdasarkan ilmu dan kiat keperawatan, berorientasi kepada kebutuhan objektif klien.

Pelayanan keperawatan di rumah sakit dan Puskesmas adalah salah satu jenis pelayanan profesional yang dilaksanakan oleh rumah sakit dan Puskesmas untuk melayani kebutuhan Masyarakat khususnya dalam bidang keperawatan yang diorganisir melalui pelayanan keperawatan.

Perencanaan keperawatan adalah suatu proses di dalam pemecahan masalah yang merupakan keputusan awal tentang sesuatu apa yang akan dilakukan, bagaimana dilakukan, kapan dilakukan, siapa yang melakukan dari semua tindakan keperawatan.

Perencanaan manajemen keperawatan diawali dengan perumusan tujuan institusi/ organisasi yang dijelaskan dalam visi misi, filosofi dan tujuan sebagai arah kebijakan organisasi.

\section{DAFTAR PUSTAKA}

1. Astar,Fatmawati.,dkk.Pengaruh Pelayanan Asuhan Keperawatan Terhadap Kepuasan Pasien di Puskesmas Takalala Kabupaten Soppeng.Journal of Management, Vol 1 (2),33-57.

2. Butar-butar,Junita.,Roymon H Simamora.2016. Hubungan Mutu Pelayanan Keperawatan Dengan Tingkat Kepuasan Pasien Rawat Inap di RSUD Pandan Kabupaten Tapanuli Tengah.Jurnal Ners Indonesia, Vol 6 (1),51-64.

3. Dermawan,D.2012. Proses Keperawatan Penerapan Konsep dan Kerangka Kerja $\left(1^{\text {st }}\right.$ ed). Yogyakarta: Gosyen Publishing.

4. Febriani,Kurnia Suci.2018. Hubungan Motivasi Kerja Perawat Dengan Pelaksanaan Asuhan Keperawatan di Puskesmas Kanor Kabupaten Bojonegoro [skripsi]. Madiun (ID): Prodi Alih Jenjang Kesehatan Masyarakat Stikes Bhakti Husada Mulia Madiun.

5. Mugianti,Sri.2016. Modul Bahan Ajar Cetak Keperawatan :Manajemen dan Kepemimpinan Dalam Praktik Keperawatan.Kebayoran Baru Jakarta Selatan : Kementerian Kesehatan Republik Indonesia. 
6. Muhiddin,Nurhayati.2013.Faktor-Faktor yang Berhubungan Dengan Kinerja Perawat Dalam Pelaksanaan Asuhan Keperawatan di Ruang Rawat Inap Private Care Center RSUP DR Wahidin Sudirohusodo Makassar [skripsi].Makassar (ID): Program Studi Ilmu Keperawatan Fakultas Kedokteran Universitas Hasanuddin Makassar.

7. Muryani.2019. Upaya Optimalisasi Penerapan Metode Asuhan Keperawatan Profesional (MAKP) Model Tim Dalam Meningkatkan Kinerja Perawat di Ruang Rawat Inap Rumah Sakit Muhammadiyah Babat [tesis]. Surabaya (ID): Fakulttas Kesehatan Mayarakat Program Magister Program Studi Administrasi dan Kebijakan Kesehatan Surabaya Universitas Airlangga.

8. Nursalam.2014.Manajemen Keperawatan: Aplikasi dalam Praktik Keperawatan Profesional.Jakarta Selatan: Salemba Medika.

9. Oxyandi,Miming.2018. Kinerja dan Lingkungan Kerja Perawat Pelaksana Dalam Melaksanakan Asuhan Keperawatan.Jurnal Ilmiah Multi Science Kesehatan, Vol9 (3), 316-332.

10. Sari,Ni Putu Wulan Purnama.,dkk.2016. Literature Review: Intervensi Keperawatan Terkini Untuk Meningkatkan Pengetahuan dan Tindakan Masyarakat Dalam Pencegahan/Pengendalian MalariaJurnal Hesti Wira Sakti,Vol 4 (1),76-93.

11. Simamora,R.H.(2005). Hubungan Persepsi Perawat Pelaksana Terhadap Penerapan Fungsi Pengorganisasian yang Dilakukan oleh Kepala Ruangan dengan Kinerjanya Di Ruang Rawat Inap RSUD Koja Jakarta Utara (Doctoral dissertation, Tesis FIK UI, Tidak Dipublikasikan).

12. Susiana.Endang.2019. Faktor yang Berhubungan Dengan Mutu Pendokumentasian Asuhan Keperawatan di RSUD DR. Soetomo Surabaya [skripsi]. Surabaya (ID): Program Studi Keperawatan Fakultas Keperawatan Universitas Airlangga Surabaya.

13. Wulandari,Putri.,dkk.2016. Faktor-Faktor yang Berhubungan Dengan Pendokumentasian Asuhan Keperawatan di Rumah Sakit Jiwa.Ners Jurnal Keperawatan, Vol 12 (2),131-142. 